\title{
Account of Livestock from Fayum Villages
}

\author{
P. Sed. 175_6. A \\ $41 \times 11 \mathrm{~cm}$. \\ Arsinoite Nome \\ $3^{\text {rd }}$ cent. B.C.
}

This papyrus is one of the private collections preserved in the museum of the faculty of Archaeology, Cairo University under "SEDMENT 1996, 175_6.A".(1)

The papyrus was vertically folded two times. It suffers from scattered worm-holes throughout the text. The document contains 49 lines. It contains a list of livestock collected from Fayum villages. The lower margin is ca. $03.50 \mathrm{~cm}$. The upper margin is missing. In some lines the writing reaches the very edge of both right-hand and lefthand margins: new section, usually beginning with village name, followed by name(s) of police chief(s), and sometimes policemen, then record of livestock.

The writing runs along the fibers on recto in a medium sized cursive script, which in places is faint. On the verso there are some illegible traces. The handwriting is the same as that of P. Sed. 175_5.A, which is from the same collection and is published in the BACPSI, XXIII, Cairo, 2006, 9-17. The handwriting of both have parallels for the $3^{\text {rd }}$ century B.C., see P. Petr. I, 27 (Fragments of Legal Records), 234 B.C.; P. Cairo Zenon, passim, e.g. P. Cairo Zenon I 59001, (Loan of Money), 273 B.C., see also E. M. Thompson, An Introduction to Greek and Latin Palaeography, New York 1973 ( $1^{\text {st }}$ Edition Oxford, 1912), facsimile no. 20, p.152.

Though the papyrus comes from Sedment, most villages mentioned belong to the Arsinoite nome i.e. they lie to the north of the Heracleopolis. ${ }^{(2)}$ The Cynopolite nome which is to the south of Heracleopolis is also mentioned, but as an ethnic for the police-

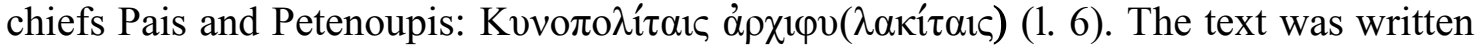
in the Fayum but found in Sedment in mummy cartonage.

Villages are grouped by merides. The first group are probably villages in the meris of Herakleides but this section is not preserved. The second group are villages in the

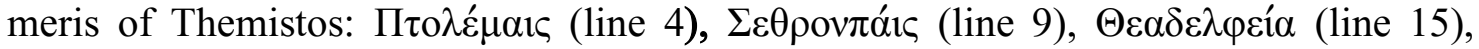

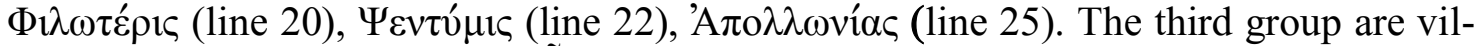

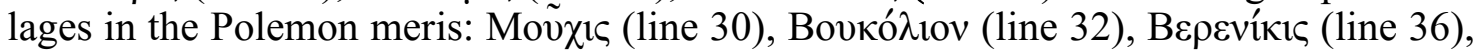

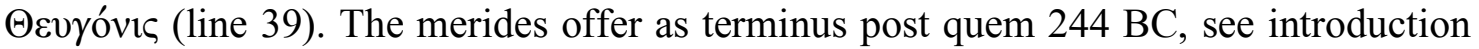

(1) We thank Willy Clarysse for kind assistance and cooperation regarding revision and correction of both the text and the introduction. We have been benefited a lot from his experience.

(2) Sedment (Ehnasya; Ancient Egyptian: Hen-en-Nisut; Graeco-Roman Heracleopolis Magna) was the principal town of the $20^{\text {th }}$ province of Upper Egypt, near the Fayum. Sedment was especially important in the First Intermediate Period, when the Egyptian kings came from here and may be also used the town as residence. The town kept its importance throughout the Egyptian history, and was again the seat of local kings in the late Third Intermediate Period. The main local god was Herishef. The temple was excavated by Naville in 1891 and Petrie in 1904, (http://www.digitalegypt.ucl.ac.uk/ehnasya/index.html) 
online of Leuven Fayum villages (Willy Clarysse, http://www.trismegistos.org/fayum/fayum2/gen_name.php).

It is probably a list of livestock handed over to the police-chiefs of various villages for supply of troops. P. Tebt. III (1), 729 ( $2^{\text {nd }}$ cent. B.C.) shows a report of the high handed proceeding of an individual who seems to have been in command of troops

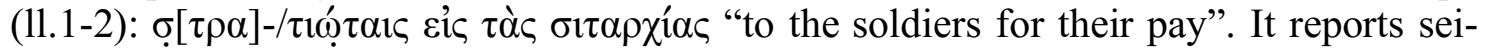
zure of sheep and cattle of the writer's neighborhood and handing over to the police-

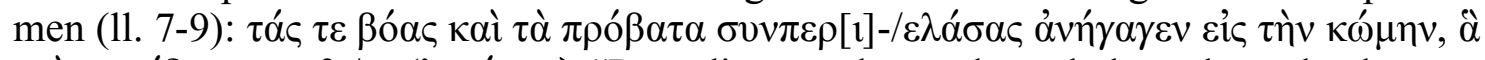

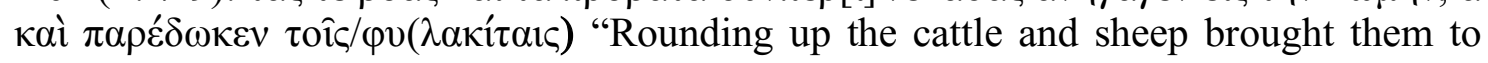
the village and handed them over to the policemen". In P. Tebt. number of the livestock from one village was high such as case of the text being published herein (P. Tebt., 11.

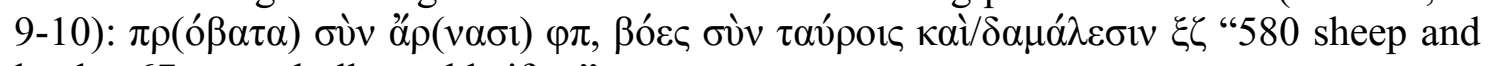
lambs, 67 cows, bulls, and heifers".

If we put in mind that number of animals is too high to be for the supply of troops and that there is no mention for sheep nor bulls, but heifers in addition to cows and calves. It could be then a list prepared for taxing purposes. "In Ptolemaic Egypt, all animals, like adults, were taxed in various ways, and therefore needed to be counted at regular intervals" see; Willy Clarysse / Dorothy J. Thompson, Counting the People in Hellenistic Egypt. II, Cambridge, 2006, Chapter 6, "counting the animals".

By the end of each meris total number of items is given (11. 27, 28 for Themistos and

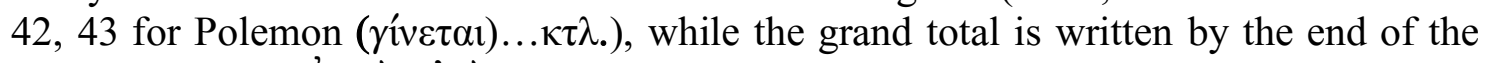

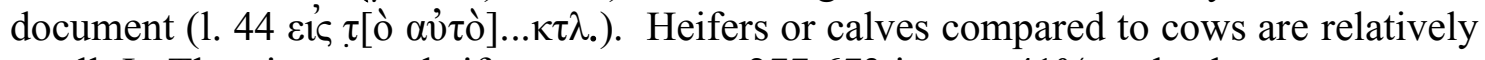
small. In Themistos e.g. heifers to cows are 277:673 i.e. ca. $41 \%$ and calves to cows are 53:673 i.e. ca. $8 \%$ (see note on 11. 26-27). The government may not have required young animals and left them to be fed for the following collection or survey.

The following table shows number of items listed per village:

\begin{tabular}{|c|c|c|c|c|c|c|c|}
\hline Lines & Village & $\beta o \tilde{c} s$ & 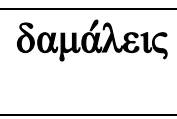 & $\begin{array}{c}\mu o ́ \sigma \chi o \\
\imath\end{array}$ & 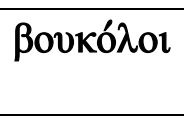 & $\pi \alpha 1 \delta \alpha ́ \rho 1 \alpha$ & rovãikes \\
\hline $1-3$ & Unknown & 150 & 16 & 4 & & & \\
\hline 04 & $\Pi \tau \mathrm{o} \lambda \varepsilon \varepsilon_{\mu \alpha}$ & 44 & 13 & $\begin{array}{ll}-- \\
--\end{array}$ & 02 & 02 & $\begin{array}{ll}-- \\
---\end{array}$ \\
\hline 09 & $\sum \varepsilon \theta \rho o v \pi \alpha ́ 1 \varsigma$ & 96 & 25 & --- & 02 & 01 & --- \\
\hline 12 & 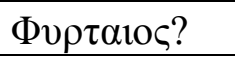 & 80 & 25 & 40 & 01 & 01 & 01 \\
\hline 15 & $\Theta \varepsilon \alpha \delta \varepsilon \lambda \varphi \varepsilon^{\prime} \hat{q}^{\alpha} \alpha$ & 62 & 42 & --- & {$[.]$.} & --- & 01 \\
\hline 20 & 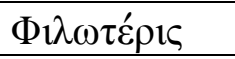 & 92 & {$[.]$.} & --- & 04 & --- & --- \\
\hline 22 & $\Psi \varepsilon v \tau u ́ \mu 1 \varsigma$ & 84 & 20 & --- & --- & --- & --- \\
\hline 25 & 'A $\pi \mathrm{o} \lambda \lambda \omega v i ́ \alpha \varsigma$ & 33 & 12 & --- & {$[.]$.} & --- & --- \\
\hline 30 & Moṽ $\chi 1 s$ & 02 & --- & --- & 01 & --- & --- \\
\hline 32 & Воvкó $\lambda$ ıov & --- & --- & --- & {$[.]$.} & --- & 01 \\
\hline 36 & Bepevíkıৎ / & 56 & 20 & --- & 01 & --- & --- \\
\hline
\end{tabular}




\begin{tabular}{|c|c|c|c|c|c|c|c|}
\hline & 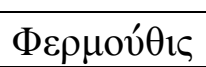 & & & & & & \\
\hline 39 & 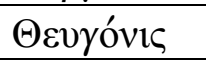 & 07 & --- & --- & {$[.]$.} & --- & 01 \\
\hline
\end{tabular}

Most of the items are written in nominative case, but some are in accusative, e.g. in

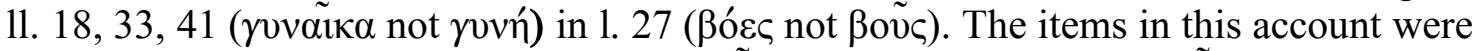
addressed to either police-chiefs $\alpha \rho \chi \imath \varphi v \lambda \alpha \tilde{\kappa i} \tau \alpha$ l or to policemen $\varphi v \lambda \alpha \tilde{\kappa i} \tau \alpha$. In 1.19 the

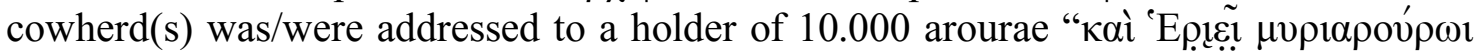
$\beta$ ○oк $[$ ó $\lambda$ ". The myriarouros was a subordinate to the nomarches responsible for infrastructure of the newly won agricultural land in the Fayum (see W. Clarysse, Nomarchs and toparchs in the third century Fayum, in Archeologia e papiri nel Fayyum. Atti del convegno internazionale, Siracusa, Quaderni del Museo del Papiro 8, 1997, pp. 69-76 and P. Sorb. III, p. 55).

Collaboration between policemen such as $\dot{\alpha} \rho \chi 1 \varphi v \lambda \alpha \tilde{\kappa i} \tau \alpha \imath$ and $\varphi v \lambda \alpha \tilde{\kappa i} \tau \alpha \imath$ with other officials is common during the early Ptolemaic period, see: e.g. P. Tebt. III (1), 708,

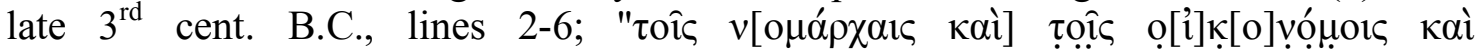

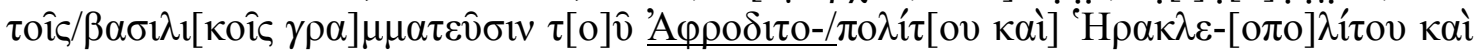

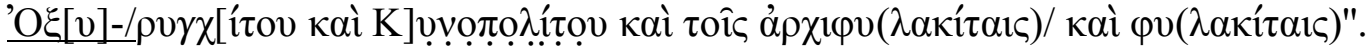

The $\dot{\varepsilon} \pi \sigma \tau \alpha \dot{\tau} \tau\rceil \varsigma \varphi v \lambda \alpha \kappa \imath \tau \tilde{\omega} \nu$ was the head of the police of a whole nome assisted by the village police chiefs $\dot{\alpha} \rho \chi \imath \varphi v \lambda \alpha \tilde{\kappa i} \tau \alpha l$. The $\dot{\alpha} \rho \chi \imath \varphi v \lambda \alpha \tilde{\kappa i} \tau \alpha l$ and the $\varphi v \lambda \alpha \tilde{\kappa i} \tau \alpha l$ had financial duties. Their main function in connection with guarding and inspection of items delivered such as livestock, liquids, crops, ... etc. beside checking wages or fees paid for workmen (see note on line 159 of P. Tebt. 5 (118 B.C.)).

The papyrus is probably an account of deliveries to be addressed to higher authority,

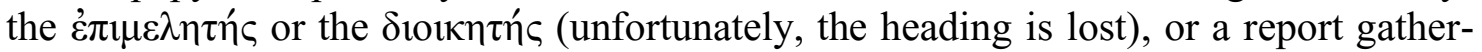
ing accounts made by different officials of the above mentioned villages and handed over to the $\alpha \rho \chi \imath \nu \nu \lambda \alpha \tilde{\kappa i} \tau \alpha \imath$ and their $\varphi v \lambda \alpha \tilde{\kappa i} \tau \alpha$.

\section{Text}

$[ \pm 13]$ к̣ai

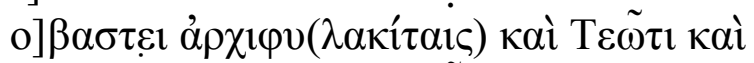

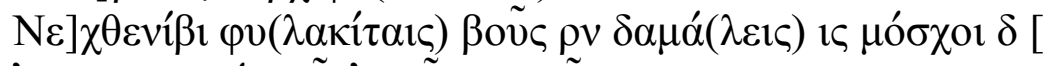

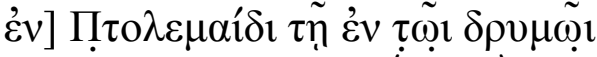

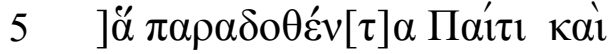

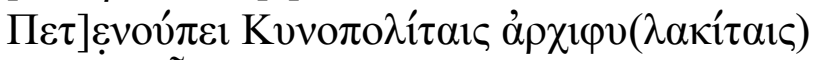

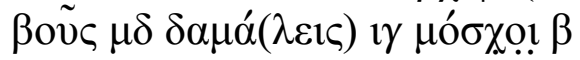

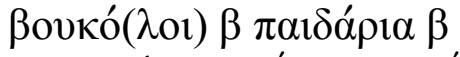

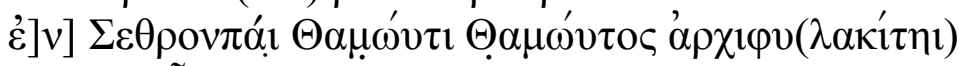

10

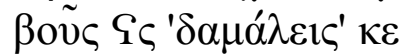

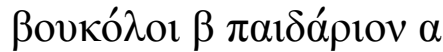

Vac

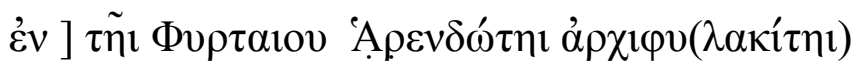




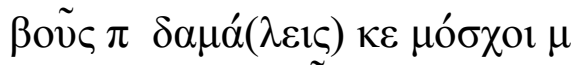

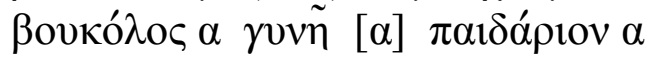

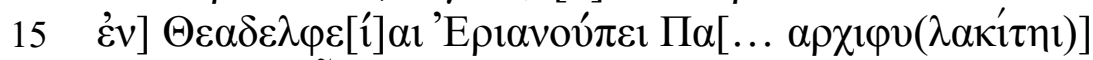

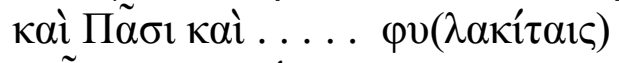

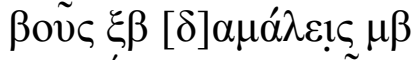

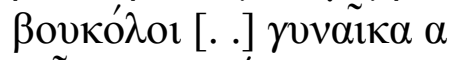

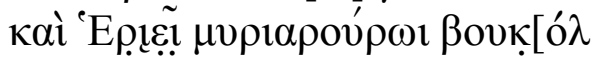

$\mathrm{Vac}$

$20 \quad \dot{\varepsilon} v]$ ]

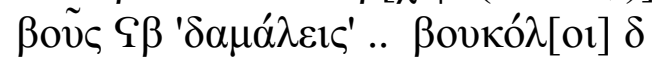

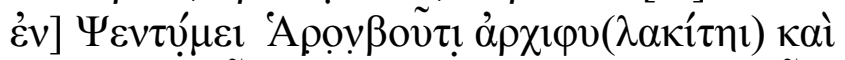

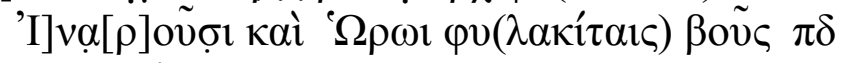

$\delta \alpha \mu \alpha ́ \lambda \varepsilon 1 \varsigma \kappa$

Vac

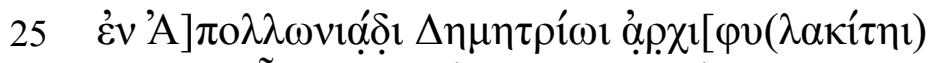

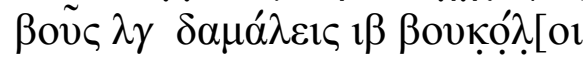

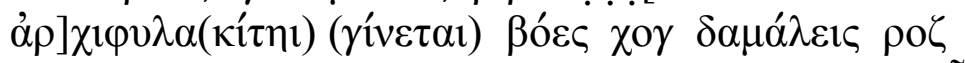

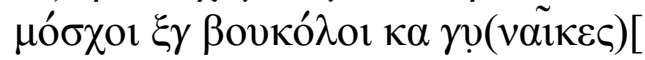

$\mathrm{Vac}$

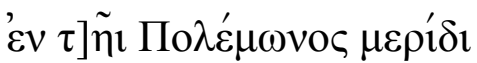

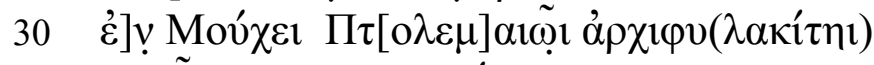

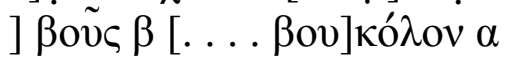

Vac

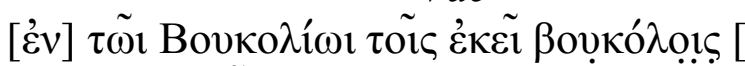

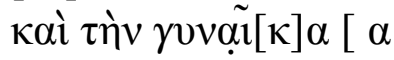

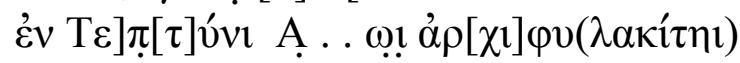

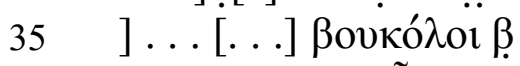

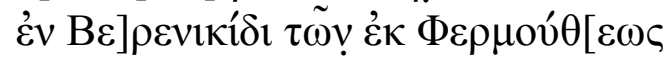

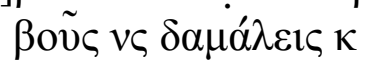

ßоvкódov $\alpha$

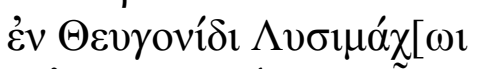

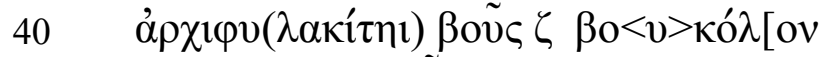

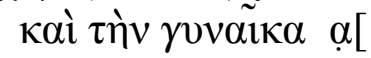

$\mathrm{Vac}$

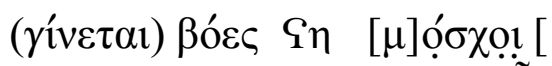

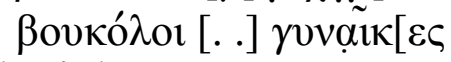

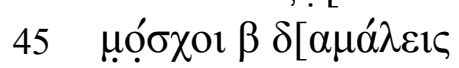

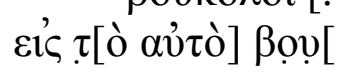




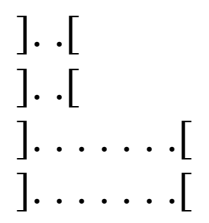

Translation

“ and

To ...bastis the police chiefs and to Teos and Nechthenibis the policemen 150 cows, 14 heifers, 4 calves In Ptolemais in the marsh

Handed them over to Pais and [to Pet]enoupis Cynopolitai police chiefs 44 cows, 13 heifers, 2 calves 2 cowherds, 2 slaves In Sethronpais to Thamous son of Thamous the police chief 96 cows, 25 heifers 2 cowherds, 1 slave In the (village) of Phyrtaios to Harendotes the police chief 80 cows, 25 heifers, 40 calves 1 cowherd, .. 1 wife, 1 slave In Theadelphia, to Herianoupis the police chief To both Pasis and .... the policemen 62 cows, 42 heifers .. cowherds, 1 wife and to Herieus, holder of 10,000 arourae, .. cowherd(s) In Philoteris N.N the police chief ... 92 cows, .. heifers, 4 cowherds

In Psentymis, to Haronbous, the police chief and To both Narous and Horos policemen 84 cows, 20 heifers

In Apollonias to Demetrios the police chief 33 cows, 12 heifers, .. cowherds To police chief Total 673 cows, 177 heifers 63 calves, 21 cowherds and ..

wives

In the division of Polemon

In Mouchis, to N.N. the police chief 
2 cows, ........., 1 cowherd

In Boukolon to ... cowherds there

And 1 wife

In Teptynis to the police chief

......., 2 cowherds

In Berenikis, to those from Phermouthis

56 cows, 20 heifers, and

1 cowherd

In Theogonis, to Lysimachos

The police chief [.]7 cows, .. cowherd(s)

And 1 wife

Total 98 cows, .. calves

Grand total

.. cowherds, .. wife (wives)

2000 calves, .. heifers ,

\section{Notes:}

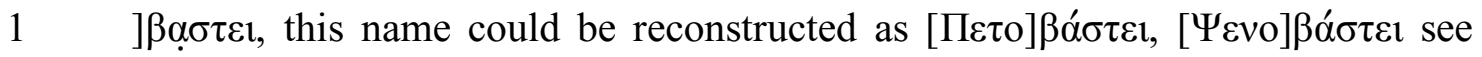
$\mathrm{P} / \mathrm{N}$ and $\mathrm{F} / \mathrm{O}$.

$3 \mathrm{~N} \varepsilon] \chi \theta \varepsilon \tilde{v} i \beta 1$, it is reconstructed in accordance with P. Tebt. III, ii, 1043 (170 B.C.), $2,22$.

$5 \quad \ddot{\alpha} \pi \alpha \rho \alpha \delta \circ \theta \varepsilon \dot{\varepsilon} v[\tau] \alpha$, this verb seems to indicate that the animals were handed over to the policemen. This is not just "counting the animals" in the village, but

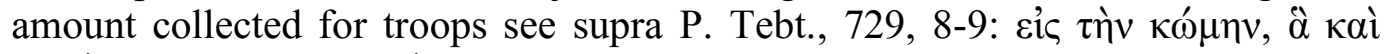
$\pi \alpha \rho \varepsilon ́ \delta \omega \kappa \varepsilon v \tau o \hat{c} \varsigma / \varphi v(\lambda \alpha \kappa i ́ \tau \alpha \varsigma)$, or a high tribute actually paid by each of these villages.

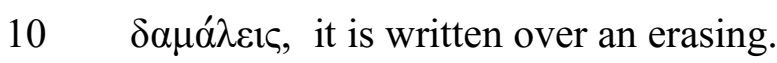

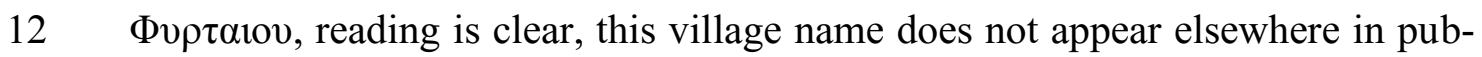
lished papyri. Cf. Herbert Verreth, A Survey of Toponyms in Egypt in the Graeco-Roman Period, Koeln/Leuven, 2008 (www.trismegistos.org/top.php).

$22 \Psi \varepsilon v \tau u ́ \mu \varepsilon 1$, this village was not known in published papyri of the Ptolemaic pe-

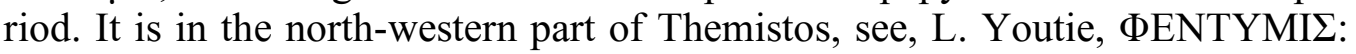
A False place name, BASP 18 (1981), pp. 174-175.

Apovßoũ 1 , though the reading of this name is clear we do not find the name elsewhere in papyri.

27-27 By comparing items of Themistos, missing items, can be deducted as follows: 


\begin{tabular}{|c|c|c|c|c|c|c|}
\hline & Boṽs & 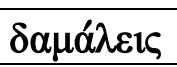 & 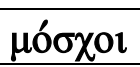 & ßovкódor & $\pi \alpha 1 \delta \alpha ́ \rho 1 \alpha$ & rovãikes \\
\hline Total written & 673 & 277 & 53 & 21 & --- & {$[.]$.} \\
\hline Present & 641 & 155 & 46 & 9 & 4 & 2 \\
\hline Missing (lacuna) & 32 & 22 & 7 & 12 & --- & {$[.]$.} \\
\hline
\end{tabular}

Young slaves are not written in the total, they could have been added to the cowherds. The high number of missing cowherds (12) could be distributed between the missing village in the beginning plus the lacunae of lines 18 "ßоvкó $\lambda$ or [. .]" and 19

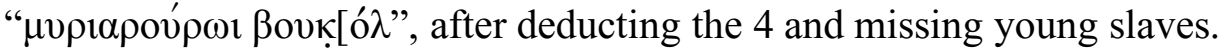

33 'Bоvкó $\lambda \iota 1$, Bоvкó $\lambda \omega v \kappa \omega ́ \mu \eta$ is well known in the meris of Themistos, but here we are in the Polemon meris. In Polemon there is also a village called

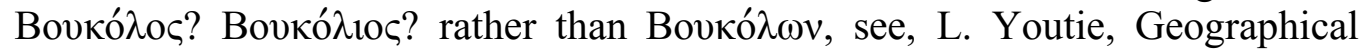
Notes, BASP 19 (1982), pp. 91-92.

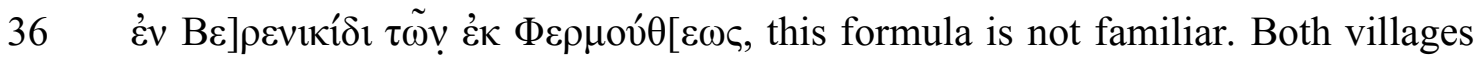
are in the Polemon meris, one may think that items were brought from Phermouthis to Berenikis to be counted there. Maybe, there is no police chief in Phermouthis.

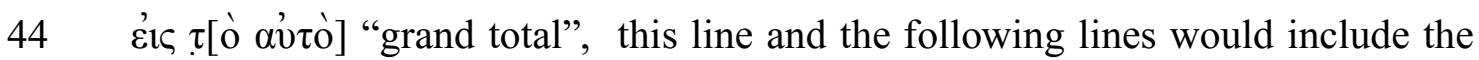
grand total of all the three merides. In that case, $\beta$ that accompanied $\mu$ ó $\chi 01$ of line 45 could be interpreted as 2000 not 2 .

$45 \delta[\alpha \mu \alpha$ a $\lambda \varepsilon 1 \varsigma$, restoration is made in accordance with its occurrence passim in the papyrus being published herein.

\section{Mohamed El-Ashiry \& Mohamed Kashaf ${ }^{(3)}$ mkashaf@lycos.com}

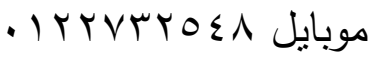

(3) Cordial thanks are due to Prof. Dr. Ola Al-Agouzi, Ex-Dean of the Faculty of Archaeology, Cairo University, for granting us photograph of this papyrus et alia. On the other hand, we do thank Prof. Dr. Alia Hanafi, Ain Shams University, for her kind approval to read this document on our behalf before the XXV International Papyrological Congress, Michigan, 2007. 


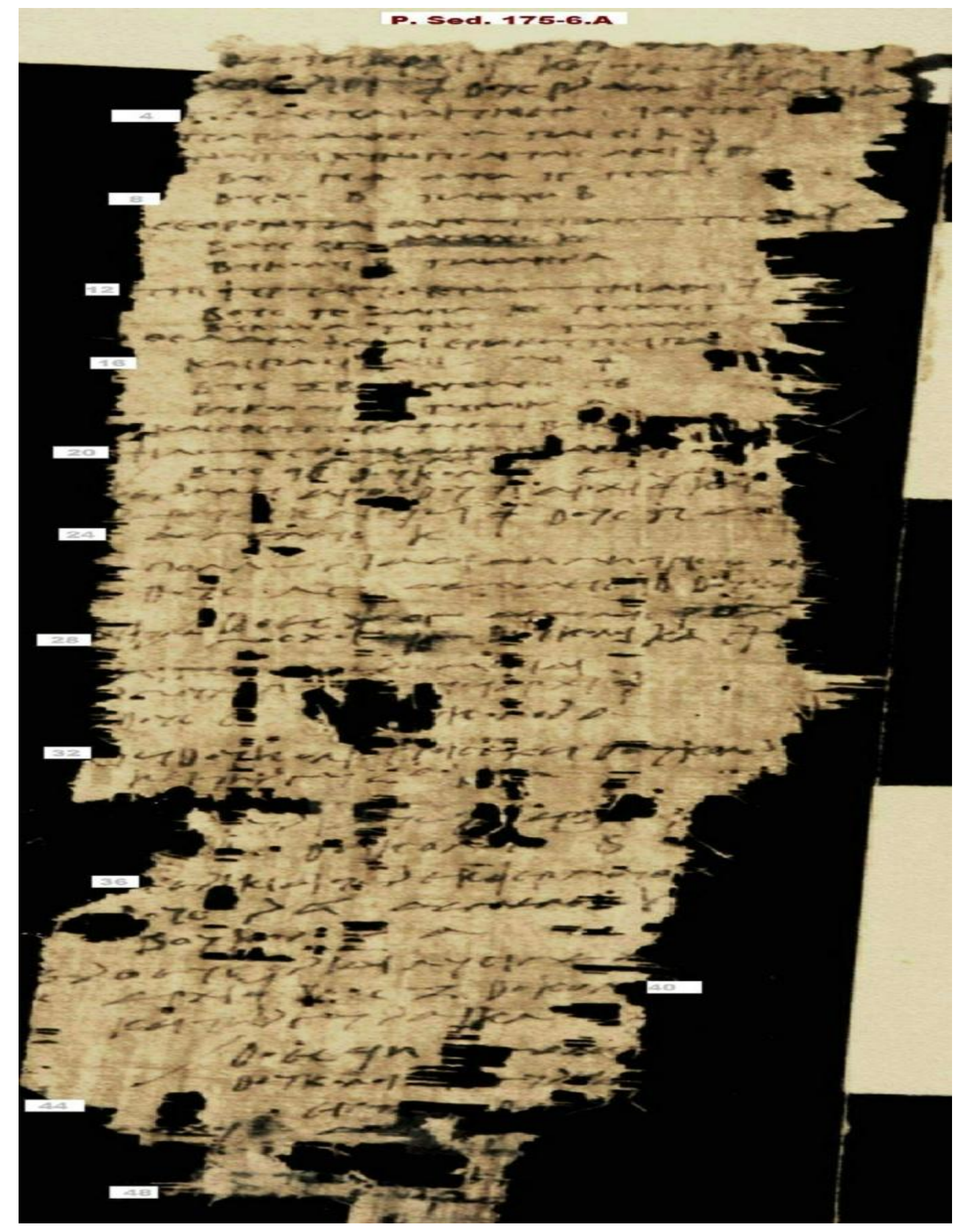

